\title{
The effect of $\Delta 9$-tetrahydrocannabinol, cannabidiol, menthol and propofol on 5-hydroxytryptamine type 3 eeceptors-a computational approach
}

\author{
Andreas C Schilbach*, Tatiana Prytkova, Susan Keun-Hang Yang \\ From 24th Annual Computational Neuroscience Meeting: CNS*2015 \\ Prague, Czech Republic. 18-23 July 2015
}

This study investigates the function of 5-HT type 3 (5HT3) receptors using a computational approach. Antagonists of the 5-HT3 receptor are currently one of the most effective therapeutic agents in treatment of chemotherapy-induced nausea, vomiting, and irritable bowel syndrome. Several experimental studies have shown the effect of pharmacological agents such as 9-tetrahydrocannabinol (THC), the psychoactive component of Cannabis, Cannabidiol (CBD), a non-psychoactive ingredient of Cannabis plant, Menthol, Propofol, and etc. on the functional human 5-HT3 receptors expressed in Xenopus oocyte as well as rat nodose ganglion neurons [1,2]. 5-HT evoked currents recorded by a two-electrode clamp technique were inhibited by ligands in a concentration dependent manner. Simulations of allosteric inhibition were modeled using Vina docking techniques with the 5-HT3 structure (see Tables 1 and 2 for results). The 5-HT3 structure was found using homology sequence similarity techniques with the neuronal nicotinic acetylcholine receptor $(\mathrm{nACH})$ and inhibitory neurotransmitter receptor for GABA(A). Results of studies with other members of the superfamily of ligand gated ion channels signified key residues involved in ligand binding sites within the transmembrane region of 5-HT3 [3]. Flexible and rigid docking simulations around key residues resulted in a number of low-energy (high affinity) configurations of ligand binding (Figure 2). The predicted residues TYR and THR may constitute a naturally occurring binding site for 5-HT3.
Table 1 Docking of Ligands on lower (THR361) binding sites of 5-HT3A

\begin{tabular}{ll}
\hline Compound - (THR361 binding site) & Binding energy (kcal/mol) \\
\hline Cyclohexane & -4.5 \\
\hline Eucalyptol & -4.5 \\
\hline Menthol & -5.6 \\
\hline Propofol & -6.0 \\
\hline
\end{tabular}

\section{Conclusion}

Experimental inhibition of 5-HT3 shows similar trend in computational binding energies to the lower binding site (THR 361).Docking calculations provide explanation of molecular basis of difference in inhibition by menthol like compounds. Similar binding energies for THC and CBD corresponds to their similar inhibition of membrane currents measured in experiment.

\section{Published: 18 December 2015}

\section{References}

1. Yang KHS, Isaev D, Morales M, Petroianu G, Galadari S, Oz M: The effect of $\Delta 9$-tetrahydrocannabinol on 5-HT3 receptors depends on the current density. Neuroscience 2010, 171:40-49.

2. Ashoor A, Nordman JC, Veltri D, Yang KHS, Shuba Y, Kury LA, Bassem Sadek B, Howarth FC, Shehu A, Kabbani N, Oz M: Menthol inhibits 5-HT3 receptor-mediated currents. J Pharmacol Exp Ther 2013, 347(2):398-409.

3. Trattnig SM, Harpsøe K, Thygesen SB, Rahr LM, Ahring PK, Balle T: Discovery of a novel allosteric modulator of 5-HT3 receptor: Inhibition and potentiation of Cys-loop receptor signaling through a conserved transmembrane intersubunit site. Journal of Biological Chemistry 2012, 287(30):25241-25254.

\footnotetext{
*Correspondence: schil105@mail.chapman.edu

Schmid College of Science and Technology, Chapman University, Orange
} CA, 92866, USA 
Table 2 Docking of Ligands on upper (TYR346) binding sites of 5-HT3A

\begin{tabular}{lll}
\hline Compound - (TYR346 binding site) & Rigid Docking - Binding energy (kcal/mol) & Flexible Docking - Binding energy (kcal/mol) \\
\hline$\triangle 9$-tetrahydrocannabinol (THC) & -7.0 & -9.2 \\
\hline Cannabidiol (CBD) & -7.0 & -8.8
\end{tabular}

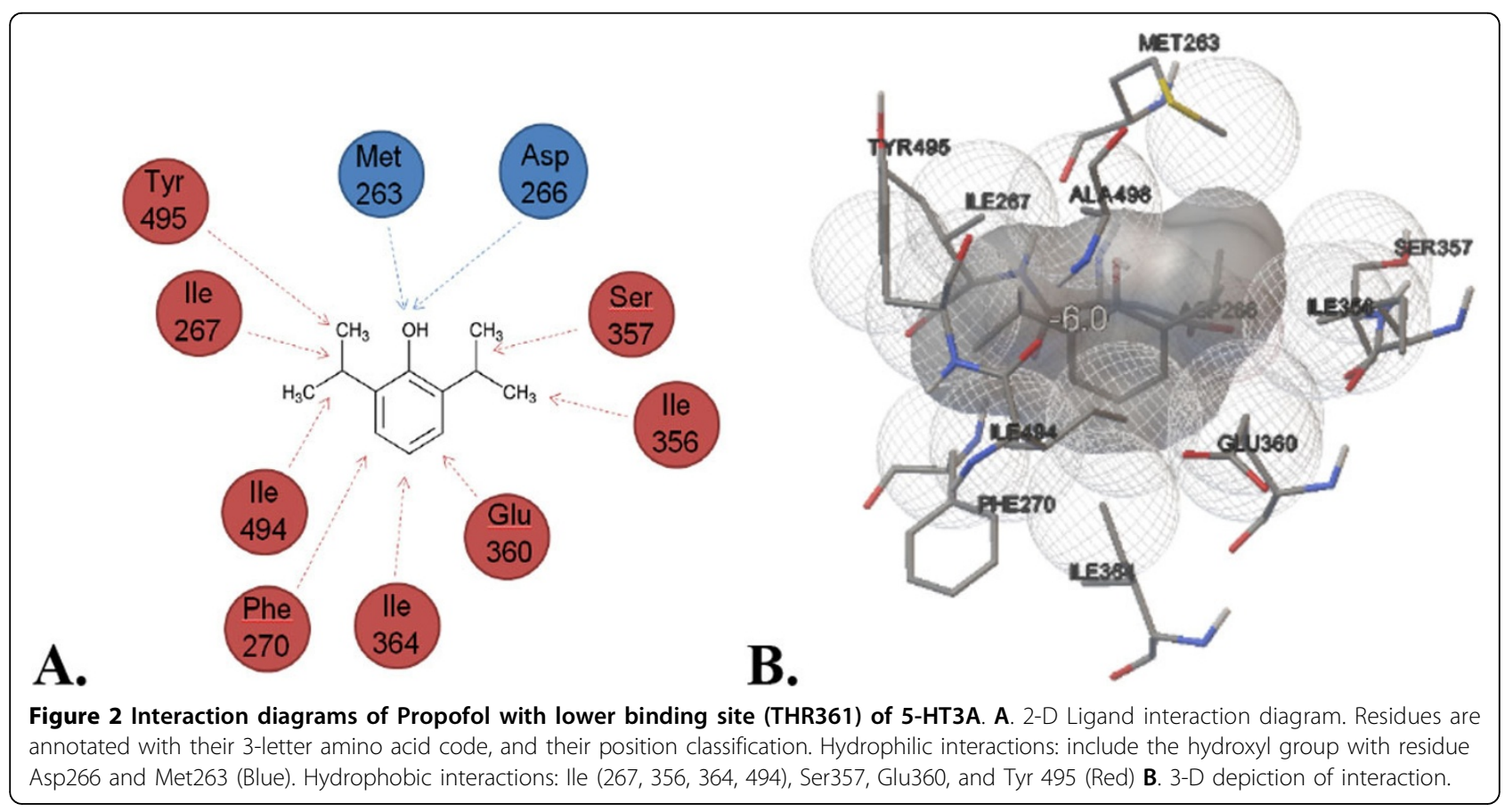

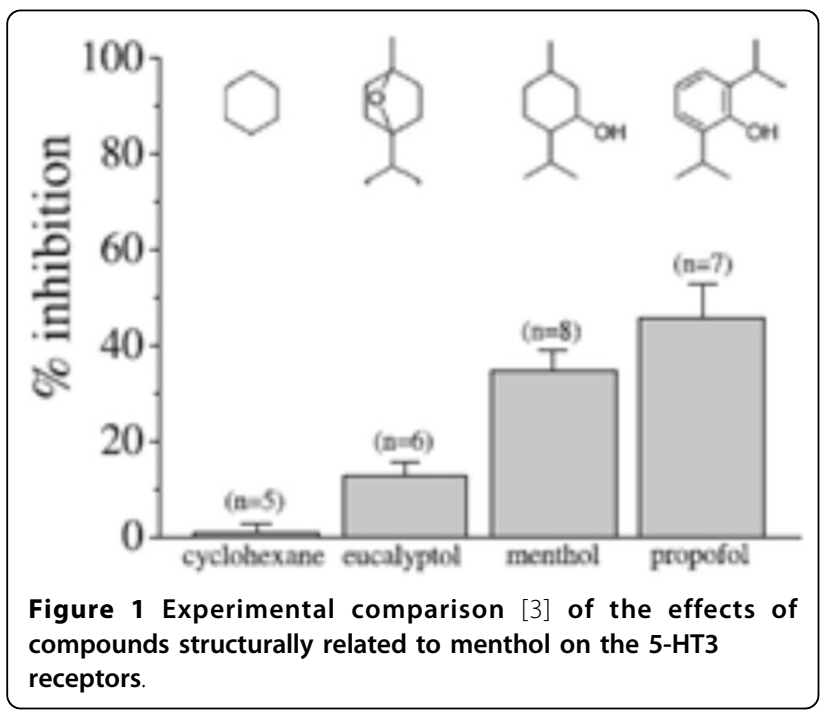

doi:10.1186/1471-2202-16-S1-P290

Cite this article as: Schilbach et al:: The effect of $\Delta 9$ -

tetrahydrocannabinol, cannabidiol, menthol and propofol on

5-hydroxytryptamine type 3 eeceptors-a computational approach. BMC

Neuroscience 2015 16(Suppl 1):P290.
Submit your next manuscript to BioMed Central and take full advantage of:

- Convenient online submission

- Thorough peer review

- No space constraints or color figure charges

- Immediate publication on acceptance

- Inclusion in PubMed, CAS, Scopus and Google Scholar

- Research which is freely available for redistribution 